\title{
Ayn Rand'ın Egoizminde Ahlakın Temellendirilmesi ve Bağlayıcılığı Problemi
}

\section{The Problem of Justification and the Binding Force of Ethics in Ayn Rand's Egoism}

\author{
Cemre Demirel ${ }^{1}$ (1)
}

${ }^{1}$ (Doktora Öğrencisi), İstanbul Üniversitesi, Sosyal Bilimler Fakültesi Felsefe Ana Bilim Dalı, İstanbul, Türkiye

\section{ORCID: C.D. 0000-0002-3279-0620}

Sorumlu yazar/Corresponding author: Cemre Demirel

İstanbul Üniversitesi, Sosyal Bilimler Fakültesi Felsefe Ana Bilim Dalı, İstanbul, Türkiye

E-posta/E-mail: cemredemirel@hotmail.com

Başvuru/Submitted: 07.03.2021 Revizyon Talebi/Revision Requested: 08.06.2021

Son Revizyon/Last Revision Received: 09.06.2021

Kabul/Accepted: 14.06 .2021

Atıf/Citation: Demirel, Cemre. "Ayn Rand'ın Egoizminde Ahlakın Temellendirilmesi ve Bağlayıcılığı Problemi." Felsefe Arkivi-Archives of Philosophy, 54 (2021): 63-80. https://doi.org/10.26650/arcp.892452

\section{ÖZET}

Bireyciliğe ve rasyonel egoizme dayalı objektivizm felsefesi ile Ayn Rand, bugün bile tartışmalı bir filozoftur. Ayn Rand her tür kolektivist ahlaka karşı çıkar ve temele toplumun faydası yerine bireyin kişisel faydasını yerleştirir. Ona göre her insan kendi mutluluğundan sorumludur ve bireyin amacı kişisel fayda maksimizasyonunu sağlamak olmalıdır. Rand, "Yemin ederim ki ne bir başkası için yaşayacağım ne de bir başkasının benim için yaşamasını isteyeceğim" sözü ile fedakarlığın zannedildiği gibi erdemli olmadığını, aksine bir ahlaksızlık olduğunu ve iyi yaşama arzusunda olan insanın ondan kaçınması gerektiğini vurgular. Ayn Rand, en başta merkeze Tanrı́yı ya da toplumu koyan ahlak anlayışları olmak üzere tüm etikleri keyfi olarak niteler. Ona göre kurucusu olduğu objektivist etik ise, isminden de anlaşılacağı üzere objektiftir ve aklın bir ürünü olmaktan çok, aklın gerçekliği keşfidir. Bu nedenle Rand'ın ahlak felsefesi insanların keyfiyetine ve kaprislerine değil, objektif gerçekliğe dayalıdır. O, doğa kanunları kadar kesin ve gerçektir. Bu makalede Ayn Rand'ın bu iddiası sorgulanmış, onun ahlak felsefesinin de keyfi öğelere yer verip vermediği incelenmiştir. Bunun adına, önce Ayn Rand'ın objektivizminin ne olduğu kısaca anlatılmıştır. Ardından kendisinin kurucusu olduğu bu ahlak felsefesinin temelinin ne olduğu ve bağlayıcılık problemine makul bir yanıt verip veremediği incelenmiştir. Bunun için, sadece makalelerinden değil, felsefesini kapsamlı bir şekilde anlattığı romanlarından da alıntılar yapılmıştır.

Anahtar Kelimeler: Ayn Rand, Objektivizm, Ahlak felsefesi, Egoizm, Bireycilik

\section{ABSTRACT}

Ayn Rand remains a controversial philosopher as her view of objectivism is based on individualism and rational egoism. Ayn Rand opposed all collectivist morality and built her philosophy on individual self-interest. She believed human beings are responsible for their happiness and should seek the maximization of self-interest. Contrary to the popular belief, she emphasized the immorality of acts of sacrifice: "I swear by my life and my love of it that I will never live for the sake of another man, nor ask another man to live for mine." Thus, she contended that a good life entailed the 
avoidance of sacrifice. Rand was a remarkable advocate of ethical egoism: she denounced all ethics based on God's command or social interest for the absence of any objective basis. Rand's philosophy of objectivism, as its name implies, is founded on objective reality instead of arbitrariness and whims. According to Rand, objectivist ethics is discovered, not invented, by mind. Nevertheless, Ayn Rand's objectivism also confronted the problem of being arbitrary. This article questions Rand's claims and investigates potential arbitrary elements in her ethics. Primarily, the paper describes her philosophy, examines Ayn Rand's grounding of morality, and elucidates how she avoids the problem of moral obligation. This study also references Rand's major novels along with her articles.

Keywords: Ayn Rand, Objectivism, Moral philosophy, Egoism, Individualism

\section{EXTENDED ABSTRACT}

This study purposed to probe whether Ayn Rand's objectivist ethics is grounded in a nonarbitrary moral basis, as she claimed. It also examined the binding force of objectivism to determine whether a moral agent can always find a due reason to act in congruence with objectivist principles.

Ayn Rand was a rational and ethical egoist. Her moral philosophy was constructed based on individual rational self-interest. She believed that the highest moral purpose of an individual entailed the pursuit of personal happiness in the light of reason. She strongly opposed altruistic and collectivistic doctrines as they mandated self-sacrifice as a virtue. In her view, the promotion of self-sacrifice signified that human beings were just a means to an end and that they were to live and act for the sake of others. Objectivism opposes all sacrifice because Rand believed that every human being was an end rather than a mere means and commanded the right to live for the self. To summarize, Rand's objectivist ethics defended selfishness and individualism against altruism and collectivism because, according to her, individual life was the ultimate goal.

However, a well-known problem of moral philosophy becomes pertinent at this point, i.e., conflict of interest. How can two moral agents agree when their interests clash? Ethical egoism functions well when both parties voluntarily accept to surrender a part of their interests to avoid further loss, but who must be sacrificed when an agreement is impossible? Objectivism recognizes every human being as the ultimate purpose; hence, it is not morally appropriate to sacrifice the interests of the other. Moreover, rational self-interest can never recommend self-sacrifice. Two objectivist principles thus appear inevitably contradictory in such a case. More importantly, why should the more powerful individual not break the rules, sacrifice the other, and maximize selfinterest?

Rand's objectivism is a form of ethical egoism that renders it difficult to discover a satisfying solution to the issue of conflict of interest. For instance, her basic political principle may be cited as follows: "No man may initiate the use of physical force against others." This value seems arbitrary in its basis when it is beneficial for an individual to harm another. Why should individuals sacrifice their self-interest while self-interest is the grounding of their morality? What is the foundation of the political principle of objectivism? Rand emphasized that rationality 
should guide the pursuit of self-interest; however, it remains unclear why and when rationality mandates that an individual should surrender self-interest.

The question, "Why should I always be moral?" is unanswered by Rand's objectivism. It may sometimes be profitable for an individual to secretly or publicly avoid the rules even as others obey them if a person is strong enough to prevent adverse consequences. It is perfectly acceptable to be a good person as long as it maximizes an individual's self-interest, but one may not always find enough reason to be moral. For instance, a person may not be sufficiently rewarded or may be punished for a moral act.

In objectivist ethics, moral obligation undoubtedly depends on reward and punishment. According to Rand, only those who obey objective reality and objectivist ethics are likely to live a good life and avoid misery. This claim evokes two problems. First, it is not realistic. Second, the boundaries between morality and success, talent, or fortune are blurred, and they can all become factors of reward and punishment.

John Galt, the protagonist of Atlas Shrugged, states, "I will never live for the sake of another man, nor ask another man to live for mine." The rejection of self-sacrifice is coherent with Rand's rational egoism; however, this study questioned whether Galt would always find enough reason not to sacrifice others for his benefit. In terms of rational egoism, the answer is no. 


\section{Giriş}

Ayn Rand pek çok açıdan tartışmalı bir filozoftur, hatta birçoklarınca filozofluğu dahi tartışmalıdır. Bir kesim tarafından çok sevilirken, bir başka kesim tarafından şiddetle nefret edilmesinin sebebi esasen ideolojiktir, zira Ayn Rand'ın radikal bireyciliği ve anti-kolektivizmi, küçük devlet anlayışı, kapitalizmin ABD’deki hâlini dahi beğenmeyecek kadar radikal bir kapitalist olması, sol görüşlü birisi açısından Rand'ın hakkaniyetli bir biçimde eleştirilmesini güçleştirmektedir. Laissez faire, laissez passer (bırakınız yapsınlar, bırakınız geçsinler) kapitalizmini savunan Rand, iktisadi açıdan liberteryenliğe yakın bir konumda olsa da metafizik ve felsefi gerekçelerle kendisini o yönde konumlandırmaz, aksine liberteryenlere şiddetle karşı çıkar ve onları akıl yerine keyfiliği ve sübjektivizmi merkeze aldıkları için sert bir şekilde eleştirir. ${ }^{1}$

Ayn Rand'ın ahlak felsefesi aynı zamanda kapitalizm ile oldukça ilintilidir, zira ona göre kurucusu olduğu objektivist etik, kapitalizmin ihtiyaç duyduğu ahlaki temeldir. ${ }^{2}$ Bir başka deyişle kapitalizmden bağımsız bir objektivist etik düşünülemez. Bunun sebebi iktisadi özgürlükler sağlanmadan bireyin sosyal özgürlüğünün de sağlanamayacak olması ve bu iktisadi özgürlüğü sağlayan yegâne sistemin laissez faire laissez passer kapitalizmi olmasıdır. ${ }^{3}$ Ayn Rand'a göre devlet yalnızca güvenliği sağlamakla mesul olmalıdır; içeride polis, dışarıda asker olarak vatandaşının güvenliğini sağlamak devletin biricik görevidir. ${ }^{4}$ Devlet piyasalara asla karışmamalı, vergiler kaldırılmalıdır. Hatta Atlas Shrugged ın baş karakteri John Galt, kendisiyle pazarlık yapmaya çalışan devlet görevlilerinden tüm devlet memurlarının kovulmasını ister. ${ }^{5}$ Rand'ın bu görüşlerinin onun bireyciliğiyle doğrudan ilişkisi vardır, zira devletin ekonomiye her müdahalesi -ki buna devletin iş kurmaya ve yönetmeye kalkışması da dahildir- aynı zamanda bireyin özgürlüğüne müdahale etmesi demektir. Zira Rand, sosyal alandaki bireycilik ile iktisadi ve siyasi alandaki bireyciliği asla birbirlerinden ayırmaz. Hür teşebbüsü ve bireysel özgürlükleri sonuna kadar savunan Ayn Rand için devlet, bireyin hayatı ve hakları üzerinde karar alma yetkisine sahip olamaz. Aksi takdirde ne bireyden ne de bireyin özgürlügünden bahsedilebilir. ${ }^{6}$

Ayn Rand'a göre henüz hiçbir filozof keyfi olmayan saf akılcı bir ahlak sistemi geliştirememiştir. ${ }^{7}$ Bu çalışmada incelenecek husus, Ayn Rand'ın kurduğu ahlak felsefesinin de keyfiyet probleminden mustarip olup olmadığıdır. Bunun için öncelikle Ayn Rand'ın ahlak felsefesi ve egoizmi kısaca anlatılacak, ardından Ayn Rand'ın objektivist etiğinin iddia edildiği gibi saf akılcı ve objektif öğelerden mi oluştuğu yoksa onun da keyfiyet problemiyle karşı karşıya mı olduğu incelenecektir.

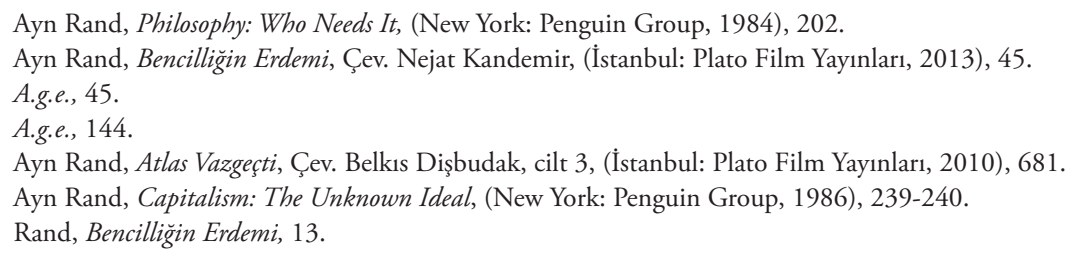




\section{Objektivist Etik}

Ayn Rand'ın objektivist etiğinin; kolektivizmin tam karşısında konumlanmış bir bireycilikten ve özgeciliğin tam karşısına konumlanmış bir bencillikten oluştuğunu söyleyebiliriz. Ahlak felsefesine objektivizm ismini vermesinin sebebi, bu ahlak kurallarının dünyanın objektif ve somut gerçeklikleri olmasıdır. Yani Rand açısından objektivizmin sunduğu ahlaki kurallar, doğa kanunları kadar net ve gerçektirler. Onların reddedilmesi, onların gerçekliğinden bir şey götürmez. Bireycilik ve bencillikle birlikte Ayn Rand'ın objektivizminin üstüne kurulu olduğu bir diğer sütun da akılcılıktır. Zira insan hayatta kalmak için akla muhtaçtır, onu kullanmadan hayatta kalamaz ve hayat, ahlakın standardıdır. ${ }^{8}$ Dolayısıyla insanın hayatta kalma aracı olan akla karşı olan, aynı zamanda hem ahlaka hem de hayata karşıdır. Ayn Rand bir etiğe ihtiyaç duyma sebebimizi şöyle açıklar:

"Öyleyse insanın peşinden koşacağı doğru amaçlar nelerdir? Onun hayatta kalmasının gerektirdiği değerler nelerdir? Bu etik biliminin cevaplaması gereken bir sorudur ve baylar bayanlar, insanın bir ahlak sistemine ihtiyaç duymasının sebebi işte budur". ${ }^{9}$

Yani Rand'a göre etiğin en temel işlevi insanın yaşamasını sağlamaktır. Bu nedenle ona göre insanı öldüren şey kötü, insanı yaşatan şey iyidir. Bunu sağladıktan sonra insanın ahlaklı olmadaki çıkarı ve amacı ise insanca yaşamaktır. Yani ahlak sadece bir parazit gibi hayatta kalmayı sağlamaz, o aynı zamanda iyi yaşamı da sağlayan bir araçtır. ${ }^{10}$

İyi yaşam ise ancak kişinin kendi mutluluğunun peşine düşmesi ile mümkündür. Ayn Rand mutluluğun peşine düşmeyi, yaşamın sürdürülmesiyle aynı şey olarak görür. Zira yaşamı kişinin nihai değeriyken, mutluluk bu yaşamındaki en üstün amaçtır, dolayısıyla yaşama uğraşı ve mutluluk arayışı ayrı şeyler olarak görülemezler. ${ }^{11}$ Yani objektivist etiğin rasyonel kişisel çıkar çatısı altında bir araya getirilebilecek üç temel bireyci amacı olduğunu söyleyebiliriz: Yaşam, iyi yaşam ve mutluluk. Ayn Rand'ın objektivist etiği, Aristoteles'in erdem etiği gibi iyi yaşamı amaçlayan bir mutluluk etiğidir. Esasında Rand'ın objektivizminin temellerini Aristoteles'te bulmak mümkündür. Aristoteles, Ayn Rand'ın ifadesiyle onu etkilemeyi başaran tek filozoftur ve tüm filozofların en büyüğüdür. ${ }^{12}$ Rand her ne kadar kendisiyle gerek metafizik gerek etik birçok konuda ayrılığa düşse de Aristoteles’in insanlığın bugün sahip olduğu medeniyetin ve bilimler de dahil olmak üzere her türlü rasyonel değerin mimarı olduğunu söyleyecek kadar Aristotelesçi bir filozoftur. ${ }^{13}$

Rand pek çok kez felsefi doktrinleri "akılcı ve mistik", "bireyci ve kolektivist" şeklinde sınıflandırır. Bu şablonları felsefe tarihine uyguladığında Aristoteles ve etkisindekileri akılcı ve

$8 \quad$ A.g.e., 17.

9 A.g.e., 26.

10 A.g.e., 28

11 A.g.e., 38.

12 A.g.e., 13.

13 Ayn Rand, For the New Intellectual, (New York: Penguin Books, 1961), 18. 
bireyci, Platon ve etkisindekileri ise mistik ve kolektivist olarak konumlandırır. Ona göre Platon, Plotinus ve St Augustine’in asırlarca hüküm süren mistisizmi ve kolektivizmi, Thomas Aquinas'ın Aristotelesçiliği ile son bulmuş ve bu sayede Rönesans yolu açılmıştır. ${ }^{14}$

Ayn Rand'ın Aristoteles'e duyduğu hayranlığın haklı gerekçeleri vardır. Öncelikle mantığın kurucusu olarak Aristoteles, Rand açısından Platon'un kalıntılarını taşıyor olsa bile insanlık tarihinde aklın mistisizme karşı galibiyetini simgeler. ${ }^{15}$ Aristoteles' in "Varlık vardır, A=A” özdeşlik ilkesi ve dış dünyanın akıldan bağımsız var olan objektif bir gerçeklik olması, Rand'ın etiğinin temellerini oluşturur. ${ }^{16}$ Öyle ki ahlak da Ayn Rand için objektif bir şekilde vardır, insana ve akla düşen ise onu inşa etmek değil, keşfetmektir. ${ }^{17}$ Dış dünyanın varlığı, ahlak da dahil olmak üzere, insan tarafından yaratılamaz, yalnızca keşfedilebilir. Yani Rand'a göre akıl hem gerçekliğin hem de objektif ahlakın keşif aracıdır.

Aristoteles'te mutluluk (eudaimonia), sırf kendi için istenen, kendinde amaç olan şeydir. ${ }^{18}$ Mutluluk kendine yeterlidir ve kendine yeterli olan şey de hem amaçtır hem de başka bir şey uğruna istenmeyen şeydir. ${ }^{19}$ Bir mutluluk etiği olan objektivizmde de mutluluğa biçilen rol aynıdır. Mutluluk hem başka bir şeye araç olmayıp kendisi için istenen şeydir ${ }^{20}$ hem de insanın hayattaki en yüksek ahlaki amacıdır. ${ }^{21}$ Dahası Ayn Rand da akla uygun yaşamın mutlu yaşam olduğunu söyleyen Aristoteles gibi ${ }^{22}$, bu mutluluk haline ancak akıl ve erdemle erişileceğini, irrasyonel talepler ve duygusal kaprislerin, yani akıldışı olanın izinden gidilerek mutluluğa ulaşılamayacağını söyler. ${ }^{23}$

Mutluluğun bir kendinde amaç oluşu ve aklın hem mutluluğa hem de hakikate ulaşmadaki rolü hususlarında uzlaşsalar da radikal bir bireyci olan Ayn Rand ile insanın toplumsal hayvan olduğunu söyleyen Aristoteles'in bireyin toplum ve devlet karşısındaki ahlaki konumu hususunda elbette derin ayrılıkları vardır. Aristoteles’te devlet, insanın politik tabiatı gereği doğal bir oluşumdur. ${ }^{24}$ Dolayısıyla insana toplum içinde yaşamayı yeğleten şey, başkalarına duyduğu sevgi ve muhabbettir. Aristoteles'e göre devlet, yalnızca vatandaşlarını koruyan ve rahatça ticaret yapmayı mümkün kılan bir oluşum değildir. Bunlara ek olarak devlet, hem diğer insanlara olan sevgimiz sonucu ortaya çıkan doğal bir oluşumdur hem de insanın iyi yaşamını amaçlar. ${ }^{25}$

Ayn Rand ise radikal bireyciliği gereği, en büyük filozof olarak tanımladığı Aristoteles'ten toplum içinde yaşam ve devletin görevleri hususlarında tamamen ayrılır. Ayn Rand'a göre

14 A.g.e., 19.

15 A.g.e., 18.

16 A.g.e., 18.

17 Rand, Capitalism: The Unknown Ideal, 30.

18 Aristoteles, Nikomakhos'a Etik, $1097 \mathrm{~b}$

19 Aristoteles, Nikomakhos'a Etik, 1097.

20 Ayn Rand, Anthem, (Signet Book, 1961), 85.

21 Rand, For Tthe New Intellectual, 100.

22 Aristoteles, Nikomakhos'a Etik, 1178.

23 Rand, For the New Intellectual, 108.

24 Aristoteles, Politika, 1253a.

25 Aristoteles, Politika, 1280b, 1281a. 
toplum içinde yaşamanın insana sağladığı iki kazanç vardır: Bilgi de dahil olmak üzere alışveriş ve işbölümü. Hatta bu kazançlar dahi sadece özgür ve akılcı insanların bulunduğu bir toplumda mümkündür, aksi takdirde parazitlerin ve fedakârlık ahlakının hüküm sürdüğü bir toplum bireye bunları sağlamayacağı gibi onu sömürecek ve başarısından dolayı cezalandıracaktır. ${ }^{26}$ Ayn Rand'ın ideal akılcı insanı elbette asosyal bir birey değildir fakat onu diğer insanlarla bir araya getiren faktör başkalarına duyulan koşulsuz bir sevgi değil, rasyonel kişisel çıkarıdır. Aristoteles, bütünün parçadan önce gelmesi gerektiğini ve devletin, aileden yahut bireyden önce geldiğini söylerken ${ }^{27}$, Ayn Rand işte bu kolektivizmin tam karşısında konum alır. Onun için devletin ya da toplumun birey karşısında öncelenmesi söz konusu olmadığı gibi, anayasa bireyi devlete karşı korumak için vardır. ${ }^{28}$ Aristoteles'te devlet, bireyin iyi yaşamını sağlama hususunda aktif rol alması gereken bir oluşumken, Rand için devletin böyle bir misyonu yoktur. Devletin yegâne görevleri güvenliği sağlamak ve hukuku tesis etmektir. ${ }^{29}$ Minarşizmi gereği Rand, devletin birey hayatına yönelik her tür müdahalesine -ne amaçla olursa olsun- karşıdır. Aristoteles'in, devletin sadece alışverişi ve güvenliği sağlamakla kalmadığını söylediği yerde Ayn Rand çizgiyi tam olarak orada çeker ve devletin görevlerini bunlarla sınırlar.

Aristoteles' in gerek siyaset felsefesi gerek etiği kolektivist öğeler barındırsa da Rand, görüldüğü üzere ona hakkını teslim etmekten çekinmez. Zira Aristoteles'in karşısındaki Platon ve Rand'ın aynı Platoncu gelenekten saydığı Augustinus, Kant, Hegel gibi filozoflar öylesine kolektivizmin tarafındalardır ki, Aristoteles'i biraz da stratejik bir hamleyle onlar karşısında bireyciliğin kurucusu olarak konumlandırır. Devlețte asker ve filozof sınıfının komün yaşaması gerektiğini savunan ve onlara özel mülkü yasaklayan Platon'un karşısında, Politika'da hocasına karşı özel mülkiyeti savunan ve özel mülkiyeti kaldırmanın birtakım erdemleri de ortadan kaldıracağını, zira ancak özel mülkiyetin olduğu bir toplumda cömertlik gibi bir erdemin mümkün olabileceğini söyleyen Aristoteles vardır. ${ }^{30} \mathrm{Bu}$ durumda Ayn Rand'ın Aristoteles'i, kendisinden çok uzak bir anlamda olsa da, yine de bireyci olarak görmesi için yeterli gerekçesi olduğunu söylemek mümkündür. Kısacası, Ayn Rand'ın objektivist etiğinin bilhassa bireycilik hususunda Aristoteles ile tamamen uzlaştığını söylemek imkânsız olsa da, aralarındaki -bir kısmı yukarıda da zikredilen- temel uzlaşıların bu farklarına galip geldiğini söyleyebiliriz.

Ruhun akla uygun faaliyetini erdem olarak tanımlayan Aristoteles gibi, Ayn Rand için de akıl erdemli hayatı mümkün kılan yegâne araçtır. Akla değil de duygulara, kaprislere, keyfiyete tabi yaşayarak ahlaklı ve dolayısıyla mutlu olmak mümkün değildir. Ayn Rand'a göre bir parazit gibi hayata tutunanlar, yani değer üretmeden değer talep edenler ya da ürettiğinden fazlasını talep edenler hem ahlaksızca yaşamaktadırlar hem de irrasyonel isteklere sahiptirler. Bunun daha iyi anlaşılması için Atlas Shrugged’ ın başkahramanı John Galt’in yaptığı meşhur konuşmadan ${ }^{31}$ şu alıntıyı yapmak yerinde olacaktır:

26 Rand, Bencilliğin Erdemi, 43-44.

27 Aristoteles, Politika, 1253b.

28 Rand, Bencilliğin Erdemi, 173.

29 A.g.e., 173.

30 Aristoteles, Politika, 1263a.

31 John Galt, Atlas Shrugged ın son bölümlerinde ülkenin radyo yayınını ele geçirir ve çok uzun bir konuşma yapar. Bir manifesto şeklindeki bu uzun konuşmada esasen Ayn Rand, kitap boyunca anlatmak istediklerini, objektivist etiği ve kapitalizmin objektivist etik içerisindeki rolünü bir monolog şeklinde anlatmıştır. 


\begin{abstract}
"Dünyaya gelmiş herkesin hiç çalışmadan yaşama hakkı olduğunu söylüyorlar, bunun tersini açıkça gösteren kanunlara aldırmaksızın her insanın asgari geçim standartlarına sahip olma hakkı olduğunu, kendisine yiyeceğini, giyeceğini, barınağını vermek gerektiğini ileri sürüyorlar. Bunun için hiçbir çaba göstermesi gerekmez, bu onun doğal ve doğuştan hakkıdır diyorlar. Vermek... Ama kimden alınarak vermek? Boşluk! Her insan, dünyada yaratılan teknolojik yararlarda eşit hakka sahiptir diyorlar. Yaratılan... Ama kimin tarafından? Boşluk! Sanayicilerin savunucusu pozunda gözükmüş korkaklar şimdi ekonomiyi şöyle tarif ediyorlar: "Insanların sınırsız arzularıyla, sınırlı miktarda sunulan mallar arasında bir ayarlama”. Sunulan... Ama kimin tarafından? Boşluk!"32
\end{abstract}

Yukarıdaki alıntıda defalarca vurguladığı üzere Ayn Rand için "Hem pastam dursun, hem karnım doysun" ${ }^{33}$ demek, özdeşlik ilkesine $(\mathrm{A}=\mathrm{A})$ aykırı olduğu için irrasyonel ve dolayısıyla da ahlaksız bir talepte bulunmak demektir. İnsan ancak rasyonalite ile hayatta kalabileceği için, irrasyonel olan yani akla aykırı olan şey aynı zamanda insan için kötüdür. Sosyalizmin ve benzeri kolektivist ekonomik sistemlerin insanlara vaadi de Ayn Rand için iki anlama gelir: Ya olmayan serveti dağıtmaya çalışmak -ki bu irrasyonellik ve dolayısıyla kötülüktür- ya da serveti hak sahiplerinden zorla alarak yağmalamak -ki bu da zorbalıktır-. Fedakârlığa dayalı olan kolektivist ekonomik anlayışlar bu sebeple hem akla karşıdır hem de ahlaken kötüdür. Akla karşı oldukları için çalışmazlar, işlevsizdirler, bu nedenle insan hayatına da karşı oldukları için kötüdürler. ${ }^{34}$ John Galt aynı konuşmanın devamında şunları der:

"Modern bir fabrikada çalışı̆̆ınız zaman size ücretiniz yalnız kendi emeğinize karşılık değil, o fabrikayı mümkün kılan tüm üretici deha için veriliyor... Onu kuran sanayicinin çalışması, biriktirdiği parayı yeni ve denenmemiş bir şeye yatırmayı seçen yatırımcının çalışması, levyelerini çektiğin makineleri çizip tasarımlamış olan mühendisin çalışması, zamanını harcayıp ürettiğin ürünü asıl yaratmış olan mucidin çalısması, o ürünün yaratılmasını mümkün kılmış olan fizik kanunlarını keşfetmiş fizikçinin çalışması, insanlara nasıl düşünüleceğini öğreten, sizin lanetleyip durduğunuz filozofun çalışması. (...) Aldığınız maaş çekinin sırf sizin fiziksel emeğinize karşılık olduğunu, o rayları kaslarınızın gücüyle ürettiğinizi iddia etmeye cesaret edecek misiniz? Sizin kaslarınızın değeri ancak Orta Çağdaki demircinin yaşam standardı kadardır. Geri kalanı Hank Rearden'dan size armağandır." 35

Ayn Rand, Marksist teorideki artı değerin bir sömürü aracı olmadığını, aksine yatırımcıların ve dehaların çalışması sonucu elde edilen ve hak edilen bir kazanç olduğunu iddia eder. Buna delil

32 Rand, Atlas Vazgeçti, cilt 3, 579.

33 Ayn Rand, bu sözü esasen The Fountainheadde "You can't eat your cake and have it too." (Pastanı hem yiyip hem de ona sahip olamazsın) ve Atlas Shrugged da "You can't have your cake and let your neighbour eat it too." (Pastanı hem komşuna yedirip hem de ona sahip olamazsın) şeklinde iki farklı şekilde dile getirir. Her iki şekilde de dile getirmek istediği, fedakârlık talep eden kolektivizmin imkânsızlığıdır. Var olmayan bir pastayı dağıtmak da mümkün değildir, fedakârlık talep eden ve var etmeden sahip olmak isteyen insanların yaptığı, imkânsızı istemektir.

34 Rand, Philosophy: Who Needs It, 98-99.

35 Rand, Atlas Vazgeçti, cilt 3, 617. 
olarak Atlas Shrugged da yatırımcıları ve dehaları üretim sahasından çeker. Bir başka deyişle tersine grev yaparak işçileri değil işverenleri greve çıkarır ve üretim durma noktasına gelir. Ayn Rand'ın görüşünde işveren sömüren, işçi sömürülen olmak zorunda değildir, hatta vergilendirmenin yüksek olduğu yahut sosyalist politikaların devreye girdiği ekonomik sistemlerde işveren sömürülen durumundadır. Zira az bulunan deha ve yetenek sahibini, her yerde bulunan kas ve beden işçisiyle eşit duruma çekmeye çalışmak, deha ve yetenek sahibinin aşağı çekilmesi, dolayısıyla sömürülmesi ve başarısından dolayı cezalandırılması anlamına gelir. ${ }^{36}$

Kapitalizmin işleyiş prensibi, Ayn Rand'ın objektivizmiyle son derece paraleldir. Bu sevgi için de böyledir. Ayn Rand'ın objektivist etiğinde sevgi de çıkar beklentisiyle yapılan bir alışveriştir. ${ }^{37}$ Bir kişiyi, sırf insan olduğu için değil, onun bize ifade ettiği değerler ve erdemler hatırına severiz, bu sebeple karşılıksız sevgi bir yanılgıdan ibarettir. Sevdiğimiz kişi için yaptıklarımız ise fedakârlık değil, ona duyduğumuz sevginin getirdiği zorunlu sorumluluklardır. Sevdiğimiz kişi için eğer belli başlı eylemleri yapmıyorsak, o kişiyi zaten sevmiyoruz demektir. O eylemleri yapıyor oluşumuz ise fedakârlık değil, bencilce bir sevginin getirdiği sonuçlardır. ${ }^{38}$

Ayn Rand'a göre tıpkı sevgi gibi ahlak da bir ticarettir. Kapitalizmde bireyler nasıl gönüllü olarak alışveriş yapan tüccarlarsa ve bu ticaretleri karşılığında kişisel faydalarını maksimize etmeyi bekliyorlarsa, birbirlerine sevgi besleyen iki kişi nasıl ki aralarında görünmez bir ticaret anlaşması varmışçasına karşılıklı fayda sağlıyorlarsa, ahlaki ve manevi alanda da bu çıkar beklentisi üzerine kurulu ticaret prensibi geçerlidir. ${ }^{39}$

Yani Rand'a göre kişi ahlak hususunda da rasyonel çıkarlarının peşinde olmalı, bu uğurda ahlaki eylemlerde bulunmalıdır. Immanuel Kant’ın deontolojisinin tam aksine, çıkar beklentisi, ahlaki eylemin ana sebebidir. Ne amaçla olursa olsun bencil bir arzu içeren eylemin ahlaklı olamayacağını söyleyen Kant'ın ödev etiğini ${ }^{40}$ birçok yerde oldukça sert bir şekilde eleştiren Rand'a göre bencilliğin ve arzuların düşman görüldüğü özgecil bir ahlak anlayışı olan ödev etiği insanlardan çok 'zombilere' uygundur. ${ }^{41}$ Bu tabiri kullanmasındaki sebep, Rand'a göre Kant'in deontolojisinin pratikte uygulanmasının, insanın tabiatı gereği imkânsız olmasıdır. ${ }^{42}$ Rand, bir tür altruizm (özgecilik) olarak tanımladığı Kant’ın ödev etiğinin insanlarca büyük ölçüde kabul gördügünü fakat bu kabulün aynı zamanda ilgili ahlak anlayışını pratikte uygulamanın imkânsızlığı sebebiyle suçluluk duygusunu da beraberinde getirdiğini söyler. ${ }^{43}$ Kişisel mutluluk arayışının ve arzuların kötülük olarak kabul edildiği bir ahlak anlayışı, Rand için ahlaktan çok ahlaksızlığı emreder, zira insanın tüm doğal arzularını ahlakın önünde bir engel saymaktadır. Oysa rasyonel olabilme kapasitesine sahip bir canlı olan insan, iyi yaşama arzusu ve amacı ile

36 Rand, Capitalism: The Unknown Ideal, 64.

37 Rand, Bencilliğin Erdemi, 42.

38 A.g.e., 42-43.

39 A.g.e., 42.

40 Immanuel Kant, Ahlak Metafiziğinin Temellendirilmesi, Çev. İonna Kuçuradi, (Ankara: Türkiye Felsefe Kurumu, 2002), 12-13.

41 Rand, For the New Intellectual, 26-27.

42 Rand, Philosophy: Who Needs It, 95.

43 A.g.e. 95. 
ahlaklı davranmalıdır. Yani Rand'a göre Kant'ın ödev etiği hem imkânsızdır hem de imkân dahilinde bile olsa ahlaken kötüdür, zira fedakârlığı emreder.

Hiçbir filozofun kaprislere ve keyfiyete dayanmayan bir ahlak sistemi geliştiremediğini iddia ederken Ayn Rand'ın özellikle hedefinde olan filozoflardan biri elbette yine Kant'tır. Rand'a göre Kant, nedenselliğin yerine ne olduğu yeterince açık olmayan ödev kavramını koymuş, bu sebeple aklı, keyfiyet ile ikame etmiştir. ${ }^{44}$ Ödev etiği, söz gelimi ebeveynlerin çocuklarına "Bunu yapmak zorunda olduğun için bunu yapmak zorundasın” demesini gerektireceğinden ötürü çocuğun gerçekçi zorunluluklar, yani nedensellikler ile bağını koparmış olacaktır. Çocuğa ahlaki bir tavsiye ya da emir verilirken, ona gerekçe olarak somut sebepler yerine döngüsel bir ödev ilkesi telkin edilecektir. Yani herhangi bir fayda ya da mutluluk getirecek olan B sonucu için, öncelikle A ahlaki eyleminin yapılması gerektiğini buyurmak yerine, A eyleminin sırf ödeve saygıdan dolayı yapılması gerektiğini söylemek, Rand'a göre insan doğasını yok saydığı kadar nedenselliği ve aklı da yok sayar. ${ }^{45} \mathrm{Bu}$ ise Rand'a göre, aklın, birazdan değineceğimiz 'keyfiyet' ile ikamesidir.

\section{Objektivist Etikte Ahlakın Temellendirilmesi ve Bağlayıcılı̆̆ı}

Ayn Rand, geliştirilmiş tüm ahlak felsefelerini, onu inşa eden filozofun keyfiyetine tabi olmakla yargılar. Ayn Rand, rasyonel ve bağlayıcı bir ahlak felsefesi keşfetmek için problemin temeline inilmesi gerektiğini şu sözlerle ifade eder:

"Hiçbir filozof, insanın bir değerler sistemine niçin ihtiyaç duyduğu sorusuna akılc1, objektif olarak ispatlanabilir ve bilimsel bir cevap vermemiştir. Bu soru cevapsız kaldığı sürece hiçbir akılcı, bilimsel, objektif etik sistemi keşfedilemez ve tanımlanamaz." 46

Ayn Rand tüm filozofların keyfiyete (arbitrariness) ve kaprislere (whims) dayalı etik sistemleri geliştirdiğini iddia ederken, kendi etiğinin, objektivizm isminden de anlaşılacağı üzere herkes tarafından gözlemlenebilen objektif gerçekliklere ve nedenselliklere dayandığını ileri sürer. Bu objektif ahlaki ilkeleri keşfedecek olan ise elbette Rand'ın en üstün hayatta kalma aracı olarak gördügü akıldır. ${ }^{47}$ Rand'a göre akıl, insanın duyuları tarafından sağlanan materyali tanımlayan ve bütünleyen bir melekedir. ${ }^{48}$ İnsan, hayvanların yaptığı gibi sadece duyularıyla hayatta kalmaya muktedir değildir, zira onun kendi besinini dahi üretmesi gerekir ki bu da akıl gerektiren bir süreçtir. ${ }^{49}$ Bu gibi sebeplerden ötürü Rand, insana özgü hayatta kalma aracı olarak tanımladığı akla karşı gelenlerin, aynı zamanda insan hayatına da karşı geldiğini söyler. Buna bağlı olarak Rand, merkeze bireyin yerine ödevi koyan etiklere karşı olduğu gibi, merkeze Tanrı'yı ve toplumu koyan etik anlayışlarının da akılcı değil keyfi olduklarını belirterek onlara karşı durur:

44 A.g.e., 95-98.

45 A.g.e., 133-134.

46 Rand, Bencilliğin Erdemi, 13.

47 Rand, Capitalism: The Unknown Ideal, 16.

48 Rand, Bencilliğin Erdemi, 24.

49 A.g.e., 25. 


\begin{abstract}
"Filozofların çoğu etik alanındaki geleneksel mistisizm tekelini kırmaya ve güya akılcı, bilimsel ve dinsel olmayan bir ahlakı tanımlamaya çalışmışlardır. Ancak onların bu teşebbüsleri sadece Tanrı'nın yerine toplumu koyarak, bunları toplumsal gerekçelerle haklılaştırmaya çalışmaktan ibaret olmuştur. Aleni mistikler, keyfi ve hesabı verilmeyen 'Tanrı iradesi'ni bir iyilik standardı olarak ve kendi etiklerinin bir gerekçesi olarak almışlardır. Neo-mistikler ise Tanrı iradesi yerine 'toplumun çıkarı'nı koymuşlar, böylece 'iyinin standardı toplum için iyi olandır' gibi bir tanımın girdabına düşmüşlerdir." ${ }^{50}$
\end{abstract}

Ayn Rand için merkeze Tanrı'yı koyan etik anlayışları ne kadar keyfiyse, merkeze toplumu koyan etik anlayışları da o kadar keyfidir, yalnızca toplumu merkeze koyanlar daha akılcı oldukları iddiasıyla ortaya atılmışlardır fakat bu bir aldatmacadan ibarettir. ${ }^{51}$ Ayn Rand ahlakı Tanrı ile temellendirenlere klasik mistikler veya ruh mistikleri derken, ahlakı Tanrı yerine toplumla temellendirmeye çalışanların bu güruhtan çok farklı olmadığını vurgulamak için onlara da "neomistikler veya beden mistikleri” adını koyar. $^{52}$

Rand'a göre ahlak da, tıpkı akıl gibi, insanın hayatta kalma araçlarından biridir. ${ }^{53}$ İnsanın bir değerler sistemi olan ahlaka ihtiyaç duyma sebebi budur. Objektif gerçekliğin nedensel ve zorunlu bir ürünü olan bu ahlakı keşfedecek aracın, yani aklın göz ardı edilmesi durumunda kaprislere dayalı keyfi etik anlayışları inşa edilir ve kaprislere dayalı tüm bu ahlaki doktrinler akla karşı oldukları için insan hayatına da karşı olmak durumunda kalırlar. Rand kaprisi, kişinin sebebini bilmeksizin veya bu sebebin öğrenilmesi ile ilgilenmeksizin sahip olduğu arzu şeklinde tanımlar. ${ }^{54}$ Yani kapris, aklın ve nedenselliğin değil, keyfin ve arzuların ürünüdür. Aslında bu bağlamda Ayn Rand'ın ahlak inşa etmek ile uğraşan herkese karşı çıktığını söyleyebiliriz. Zira ahlak ona göre keşfedilebilir bir şeydir ve bu keşif işi de akla aittir. ${ }^{55}$ Ahlakı keşfetmek yerine onu inşa etmeye kalkışmak ise objektif gerçekliğin ve nedenselliğin keşfinden çok yapay buyruklar içereceğinden ötürü, bu teşebbüsler akıl yerine keyfiyete ve kaprislere dayalı birer inşa olmak zorunda kalacaklardır.

Ayn Rand'da aklın keşfedeceği bu nesnel ahlakın dayandığı temel ise kişisel çıkardır. ${ }^{56}$ Her insan kendi rasyonel çıkarını arttıracak eylemlerde bulunmalı ve asla kendisini başkaları uğruna feda etmemelidir. Ahlakın nihai amacı ise kişinin kendi hayatıdır. Kişinin kendi çıkarını temel alarak kendi hayatını amaç edinmesi, elbette bir başkasının yahut başkasının çoğulu olan toplumun isteklerini baz almasından daha makul bir zemine geçiştir fakat bu da birazdan değineceğimiz üzere etikle ilgili birtakım başka sorunlara gebedir.

Ayn Rand için özsel bir değer olan hayat, kendinde amaçtır. Bununla birlikte hayat, insanın değerler standardıdır. Tüm değerler, hayatın kendisinden türemek zorundadırlar. Zira Rand'a

50 A.g.e., 13

51 Rand, Philosophy: Who Needs It, 197.

52 Rand, For Tthe New Intellectual, 138, 148, 149, 158.

53 Rand, Bencilliğin Erdemi, 27.

54 A.g.e., 12.

55 Rand, Capitalism: The Unknown Ideal, 21.

56 Tara Smith, Ayn Rand's Normative Ethics: The Virtuous Egoist, (Cambridge: Cambridge University Press, 2006$), 23$. 
göre değer de dahil olmak üzere tüm kavramlar epistemolojik olarak hayat kavramına bağlıdır. ${ }^{57}$ Bu sebeple hayatı destekleyenler iyi, hayata karşı gelenler kötüdür. İnsan hayatına zarar veren herhangi bir şey, nihai değer olan ve tüm değerlerin kendisinden türediği hayata zarar verir ve diğer değerlerin var olmasına bile müsaade etmez. Hayatın olmadığı yerde erdemden, mutluluktan, iyiden, güzelden yani herhangi bir değerden söz edilemez.

Etik anlayışının merkezine hayatı koyan ve onu hem nihai amaç hem de nihai değer olarak gören Rand, işte buradan hareketle insanın hayatına ve dolayısıyla kişisel çıkarına zarar veren her şeyi kötü addeder. Bir rasyonel egoist ve aynı zamanda ahlaki egoist olarak Rand, insanın rasyonel kişisel çıkarına faydalı olan şeyi yapması gerektiğini savunur.

Özetle, hayatı insanın nihai değeri ve amacı, kişisel çıkarı ise ahlakının temelidir. Fakat bu temellendirme, her ne kadar Ayn Rand akılcı insanların çıkarlarının asla kesişmeyeceğini iddia etse $\mathrm{de}^{58}$, çıkar çatışmasının kaçınılmaz şekilde olduğu durumlarda yetersiz kalmaktadır. Örneğin iş başvurusunda bulunan benzer yeteneklere sahip iki adaydan birinin diğerine çelme takmaması için ya da torpil ile haksız bir şekilde işi kapmaması için objektivist etik tatmin edici bir cevap vermekten uzaktır. Eğer tüm toplum bu şekilde ahlaksız yollarla iş edinirse, uzun vadede bunun benim de zararıma olacağı açıktır. Fakat tek bir benlik sahibi birey olarak benim bu tür oyunlara başvurmamam için, objektivizm geçerli bir neden sunamaz. Zira ben kendi hayatım için ve kişisel faydam için doğru olanı yapmakla mükellefimdir ve diğer aday, bana yaşatacağı ufak bir vicdan muhasebesi dışında benim için pek bir şey ifade etmemektedir. Hayatın nihai amaç, kişisel çıkarın da ahlakın temeli yapılmasının yol açtığı zorluklardan birisi, tek başına benim ahlaksızlık yapmamam için her zaman yeterli gerekçeyi sağlayamamasıdır.

Ayn Rand, bu duruma cevap olarak çıkar çatışmasının akılcı ve özgür toplumlarda yaşanmayacağını iddia etmekte ve problemi adeta görmezden gelmeyi tercih etmektedir. ${ }^{59}$ Fakat o da kişisel çıkarın ahlakın temeli yapılmasının kaçınılmaz olarak doğuracağı sonuçları bildiğinden ötürü bir sosyal prensip geliştirir. Bu sosyal prensip Atlas Shrugged da defalarca dile getirilen "Ne bir başkası için yaşayacağım ne de bir başkasının benim için yaşamasını isteyeceğim” prensibidir. Ayn Rand bu prensibi Virtue of Selfishness'ta şöyle açıklar:

\footnotetext{
"Objektivist etiğin temel sosyal prensibi, tıpkı yaşamın kendi başına bir amaç olması gibi, her insanın da kendi başına bir amaç olduğu, başkalarının refahı ya da amaçları için amaç olmadığıdır ve bu yüzden insanın ne kendisini başkalarına feda ederek ve ne de başka insanları kendisine kurban ederek kendisi için yaşaması gerektiğidir. Kendisi için yaşamak, insanın en yüksek ahlaki amacının, kendi mutluluğunu başarmak olduğu anlamına gelir." ${ }^{\prime 60}$
}

57 Rand, Bencilliğin Erdemi, 17-18. Bruce J. Avolio ve Edwin E. Locke, "Contrasting different philosophies of leader motivation: Altruism versus egoism,” The Leadership Quarterly 13 (2002): 171.

58 Rand, Bencilliğin Erdemi, 81-82.

59 A.g.e. 81-82.

60 A.g.e., 35. 
Kişinin nihai amacı ve nihai değeri kendi hayatı ve ahlakının temeli de kişisel çıkarıysa, bu durumda Ayn Rand'ın bu sosyal prensibi neye göre geliştirdiği söylenebilir? Kendi hayatını kendi nihai amacı edinen bir insan, niçin her insanın hayatını kendinde amaç olarak görmekle mükellef olmalıdır? Eğer bireyin kişisel çıkarını arttıran şey akılcı ve iyiyse, bu insan niçin başkalarına asla zarar vermemek üzere bir hassasiyet geliştirmek durumunda olmalıdır? İş başvurusunda bulunan aday, tek başına bir hile kaçamağı yaptığı takdirde işe alınabilecekken, niçin birdenbire Kant'ın deontolojisindeki gibi tüm insanları kapsayan bir maksim ile hareket etmektedir? John Galt'in meşhur "başkaları için kendimi feda etmeyeceğim" ilkesi rasyonel egoizm ile uyumluyken, bu mottonun devamındaki "kendim için başkalarını feda etmeyeceğim” ilkesi nereden gelmektedir? Egoizmin nesnel hakikatlerinden mi, yoksa Ayn Rand'ın kaprislerinden mi? Bu sorunun cevabı ikinci şık gibi durmaktadır, zira kişisel çıkarı temel alan bir ahlaki öğretinin kişisel çıkardan taviz verme konusundaki kriteri net değildir.

Ayn Rand hem bir rasyonel egoist hem de bir ahlaki egoisttir. Rasyonel egoizm, kişinin kendi çıkarına olan eylemin rasyonel olduğunu söylerken, ahlaki egoizm, bu eylemin ahlaken iyi olduğunu söyler. ${ }^{61}$ Kişinin yararına olan eylemin rasyonel olduğunu söylemek makulken, bu eylemin aynı zamanda ahlaklı olduğunu söylemek için elimizde yeterli gerekçe yoktur. Ayn Rand, rasyonellik ile ahlakı, egoizm çatısı altında birleştirmeye çalışsa da kişisel çıkarı arttıran, yani rasyonel olan eylemin her zaman ahlaklı olması mümkün değildir. Elbette çoğu zaman ahlaklı davranmak, bireye birçok maddi ve manevi yarar sağlar. Bu gibi durumlarda rasyonellik ile ahlaklılığın örtüştüğü muhakkaktır. Ancak ahlaklı davranmak her zaman bireyin kişisel çıkarına hizmet etmemektedir. Bu durumda egoizm çatısı altında evlendirilmeye çalışılan rasyonellik ve ahlak, birbirleriyle çatışmak durumunda kalacaktır. Yahut Ayn Rand'ın belirlediği sosyal prensip gibi, ahlakının temelini oluşturan kişisel çıkar kavramıyla uyuşmayan yeni ilkeler belirlenerek bu sorun çözülmeye çalışılacaktır. Fakat böyle bir çözüm girişimi Ayn Rand'ın hem nihai değer olarak belirlediği kişinin kendi hayatına hem de ahlakın temeli olarak belirlediği kişisel çıkara uymayan, keyfi ve çelişkili bir teşebbüstür. Kısacası sorumuz oldukça nettir: Kişisel çıkarı temele alan seküler bir ahlak, neye dayanarak zaman zaman kişisel çıkarımdan vazgeçmemi tembihlemektedir?

Elbette ahlaki egoizmde de ahlaki egoizmin bir türü olan objektivizmde de kişi kendisinden başkasını düşünmeyen karikatürize bir bencil değildir, aksine her iki ahlaki öğreti de kişiye başkalarını düşünmek ve yardımsever olmak için gayet makul gerekçeler sunmaktadır, ta ki bu durum failin fayda maksimizasyonuna hizmet edene kadar. Yaptığı eylemin kişiye sağladığ maddi, psikolojik ya da sosyal faydalar toplamı, eylemin maliyetinden fazla olduğu sürece, kişinin o eylemi yapmak için makul gerekçeleri vardır. Ancak başkasını düşünmenin kişi için haddinden fazla maliyetli olduğu türden çıkar çatışması durumlarında, bu makul gerekçeler ortadan kalkmaktadır. Bu durumda Ayn Rand'ın getirmiş olduğu sosyal prensip, herhangi bir temele sahipmiş gibi gözükmemektedir.

61 Robert Shaver, "Egoism", The Stanford Encyclopedia of Philosophy, ed. Edward N. Zalta, (Spring 2019 Edition), erişim 14.03.2021, https://plato.stanford.edu/archives/spr2019/entries/egoism/. 
Benzer durum, Ayn Rand'ın objektivizm adına getirmiş olduğu politik prensip için de geçerlidir. Bu politik prensibe göre meşru müdafaa durumları hariç hiç kimse bir diğerine karşı fiziksel güç kullanımı başlatamaz. ${ }^{62}$ Fakat temeli bireyin rasyonel kişisel çıkarına dayanan bir etik sisteminde, şiddet kullanımının da neden her zaman yanlış olmak zorunda olduğu açıklanamayacaktır. Kısıtlı kaynaklara sahip bir mekânda A ve B kişilerinin -ya da topluluklarınınyaşadığını varsayalım. Tüm kaynaklar bir şekilde B’nin eline geçmiştir ve A’nın hayatta kalmak için dahi yeterli kaynağı yoktur. Öte yandan B'nin de A'ya bakmak ve onunla kaynaklarını paylaşmak için yeterli gerekçesi yoktur, zira A'nın B’ye sunacağı herhangi bir meziyeti yoktur ve dolayısıyla B'nin A ile işbirliği yapmak için yeterli gerekçesi yoktur. Bu durumda A'nın önünde iki seçenek vardır: Ya fiziksel güç kullanarak B’nin sahip olduğu kaynakları ele geçirecektir ya da yok olacaktır. Kişisel çıkarı A’ya, B’nin hatırına ölmeyi kabullenmesi gerektiğini söylemeyecektir, bu çıkar A'ya hayatta kalmak için her yolu denemesi gerektiğini tembihleyecektir. A'nın B'ye saldırmamak için sunacağı gerekçeler, kişisel fayda bağlamında kendi ölümünü kabullenmesine, yani hayatından vazgeçmesine yetmeyecektir. Bilhassa nihai amacı kişinin hayatının kendisi ve hayatta kalmak olan objektivizme göre, A'nın kendini B için feda etmesinin hiçbir rasyonel gerekçesi olamaz. Fakat objektivizmi bir kapitalizm etiği, hatta kapitalizmin ihtiyacını duyduğu ahlaki temel ${ }^{63}$ olarak tanımlayan Ayn Rand'ın özel mülkiyetin gaspını onaylaması da mümkün gözükmemektedir. Bu durumda şiddet kullanımının neden her zaman kişisel çıkara aykırı olması gerektiğini söyleyecek akılcı bir gerekçe yoktur. Özellikle de ahlakı "kişinin hayatta kalması için gereken değerler sistemi” olarak tanımlayan Rand'ın, A'nın B’ye saldırmaması ve onun mülkiyetini gasp etmemesi hususunda sunabileceği gerekçeler hem keyfi hem de çelişik olmak durumunda kalacaktır.

Ayn Rand'ın ahlak felsefesinde çözümsüz kalan bir diğer husus da ahlakın bağlayıcılığıdır. Ahlakın temellendirilmesi ve bağlayıcılı̆̆ı şüphesiz ki ayrı kavramlardır. Temellendirilmiş bir ahlak da hâlâ bağlayıcı olmayabilir. Bağlayıcı bir ahlak, ödül ve ceza vaadinde bulunmalıdır ki o ahlaki kurallara uymak konusunda bir zorunluluk hissi geliştirmek mümkün olsun. "Bu kurallara uymam ve uymamam durumlarında beni neler bekliyor?” sorusuna ne kadar isabetli cevaplar veriyorsa bir ahlaki öğreti, onun o ölçüde bağlayıcı olduğunu da söyleyebiliriz. İnananlarına "Bu kurallara uymalısınız fakat bu kurallara uymak size bir fayda sağlamayacağı gibi uymamak da bir zarar getirmeyecek” diye seslenen bir ahlaki öğreti, hatta bu bir din bile olsa, bağlayıcı değildir. Ahlakı bir ticaret olarak gören ve iyiliğin ödül beklentisiyle yapılması gerektiğini savunan Ayn Rand'ın kriterleriyle yargılayacak olursak bu tür bir ahlakın hiçbir bağlayıcılığı olmayacaktır.

Ayn Rand kuşku yok ki bu bağlayıcılık probleminin farkındadır ve buna cevap olarak yaşamanın yolunun objektivist etik olduğunu, buna uymayanların hayatta kalamayacaklarını yahut ancak düşük standartlarda, insana yaraşır olmayan şekillerde yaşayabileceklerini söyler. Ayn Rand'ın objektivizm felsefesi, kapitalizmi de bünyesinde barındırır. Objektivizmi Ayn Rand, kapitalizmin metafizik ve ahlaki yönü olarak tanımlar. ${ }^{64}$ Bir insan, kapitalizmin ve onun

62 Rand, Bencilliğin Erdemi, 44.

63 A.g.e., 45.

64 Rand, Capitalism: The Unknown Ideal, 9-10. 
moral dayanağı olan objektivizmin temel ilkelerine uyduğu sürece ahlaklıdır ve bu ölçüde doğa tarafından ödüllendirilecektir. Yaşamanın yolu objektivist değerler olduğu için, bu değerlere uymayan kişiler de doğa tarafından cezalandırılacaktır. Issız adada tek başına yaşayan bir insan nasıl ki doğanın kurallarına boyun eğmek ve oyunu kuralına göre oynamak zorundaysa, aynı zorunluluk toplum içerisinde yaşayan insan için de geçerlidir ve $1 s s ı$ adada geçerli olan kurallar büyük ölçüde toplum içinde de geçerlidir. Issız adada var olma mücadelesi veren insanın birtakım kuruntulara ve kaprislere göre karar vermesi, aklı ve mantığı devreden çıkararak doğa kanunlarını görmezden gelmeyi tercih etmesi, doğa tarafından görmezden gelinmeyecek ve kuvvetle muhtemel bu kişinin hayatına mal olacaktır. Issız bir adada hayatta kalmanın kuralları bellidir ve bu kurallar akıl ve rasyonalite eşliğinde doğa kanunlarını göz önünde bulundurarak kararlar almayı gerektirir. Aynı durum toplum içinde yaşayan insan için de geçerlidir ve insan, rasyonalite yerine toplumun kaprislerine göre yaşamayı tercih ederse er ya da geç doğa tarafından cezalandırılacaktır. Ayn Rand'ın etiğindeki bağlayıcılık, yani "Ben bu kurallara niçin uyayım ki?” sorusunun cevabı budur: Yaşamak için ve insana yaraşır şekilde yaşamak için.

Ayn Rand, objektivizmin bağlayıcılığını göstermek adına The Fountainhead ve Atlas Shrugged gibi ünlü romanlarında bir nevi karma sistemi uygular. Bu romanların sonunda objektivizmin, liberalizmin ve kapitalizmin ilkelerine uygun yaşayan karakterler mutlu sonlarla ödüllendirilirken, bu ilkelere karşı gelen yahut bu ilkelere karşı gelmese dahi yine de bu ilkeler doğrultusunda yaşamayan karakterler felaketlerle ve kötü sonlarla cezalandırılırlar. İşte Ayn Rand'ın romanlarında uyguladığı pozitivist karma budur. Peki hayat gerçekten böyle midir? Herkese şaşmaz bir şekilde yaptığını mı verir? Ayn Rand buna kanıt olarak ironik bir şekilde suçluları ve diktatörleri gösterir. ${ }^{65}$ Ona göre suçlular ve diktatörler gibi kimseler amaçlarını ancak kısa bir süreliğine gerçekleştirebilirler fakat nihai olarak kaybetmeye mahkumdurlar. ${ }^{66}$ Oysa yeterince güçlü suçlular olarak tanımlayabileceğimiz diktatörler çoğu zaman ahlaki kuralları tanımamış ve bunların pek azı hak ettiğini bulmuştur. Ayn Rand'ın bu gibi insanların amaçlarını 'kısa süreliğine' gerçekleştirebileceklerini söylerken kastettiği kısa süre eğer bu insanların hayatları boyuysa, o halde Ayn Rand'ın nihai amacını hayat olarak gördüğü objektivist ahlakı, ölülerin hayatları için olmalıdır.

Herkes belirli ahlaki ilkelere sahip insanlardan oluşan bir toplumda yaşamak ister. Bu, kişisel çıkarlarla da örtüşür. Herkesin herkesle savaş halinde olduğu Hobbes'un doğal durumundaki gibi kaotik bir dünyada yaşamak elbette arzulanır bir şey değildir. Fakat başkalarının ahlaklı olmaları benim için faydalıyken, benim ahlaklı olmam benim için her zaman faydalı mıdır? Erdem etiğini ya da ödev etiğini savunan filozoflara göre ne olursa olsun ahlaklı olan yapılmalıdır, fakat konumuz gereği bu soruyu ahlaki egoizm bağlamında ele alacağız. Kişisel çıkarı temel alıyorsak ve öte dünyaya dair inançlarımızın da olmadığını varsayıyorsak, bu durumda ahlaklı olmanın her zaman kişisel çıkara hizmet ettiğini söylemenin bir yolu yoktur. Elbette ahlaki egoizme göre kişisel çıkara hizmet eden şey zaten ahlaklıdır, fakat şimdilik ahlaklıdan kasıtla hemen hiç kimsenin itiraz etmeyeceği dürüst olmayı, ahlaksızdan kasıtla da yalan söylemeyi ele alalım. Kişi, dürüst olması

65 Rand, Bencilliğin Erdemi, 29.

66 A.g.e. 29. 
sebebiyle cezalandırılabileceği ya da dürüst olmaması durumundaki kadar ödüllendirilmeyeceği pek çok durumla karşılaşabilir. Aynı şekilde yalan söylemekle ödüllendirileceği ya da yalan söylememesi durumundaki kadar cezalandırılmayacağı pek çok durumla da karşılaşabilir. Bu durum; şiddet, gasp, cinayet gibi tercih edilmeyecek birçok eylem için de geçerlidir. $O$ halde kişi yeterince güçlüyse, yasalardan ve insanların yargılamalarından da kaçabiliyorsa, bu eylemler de onun kişisel çıkarını en fazla arttıran eylemlerse, niçin bunları yapmamak zorunluluğunda olsun? Ahlaki egoizme göre toplum nezdinde kötü sayılan bu eylemler, bireyin kişisel fayda maksimizasyonunu sağlayan seçenekler oldukları sürece iyi eylemlere dönüşmek zorundadırlar.

Ahlaki egoizme göre toplumun ahlaklı olması bireyin kişisel çıkarına hizmet ederken, bireyin bu kalabalığın içinde tek bir 'ben' olarak kötülük yapmaması için her zaman yeterli gerekçe yoktur. Bu sebeple Ayn Rand'ın kendi etiğinin bağlayıcılık problemine de bir cevap sunduğunu göstermek adına eserlerinde objektivizmin yolundan giden kahramanları daima mutlu sonla ödüllendirmesi pek de gerçekçi gözükmemekte, hatta bir tür pozitivist karma sistemini andırmaktadır. Adam Smith'in iktisattaki görünmez elinin ahlak evreninde geçerli olan bir türü gibi, Ayn Rand'ın çizdiği dünyada da görünmez bir el yahut doğa, objektivistleri muhakkak ödüllendirmekte, diğerlerini ise cezalandırmaktadır. Ayn Rand'ın mistisizm olarak gördüğü herkesin hak ettiğine kavuştuğu öte dünya inancını bu dünyaya taşımaya çalıştığı; suçluların ve diktatörlerin er geç hak ettiklerini bulacakları iddiasından ve romanlarındaki karma sisteminden anlaşılmaktadır. Bunun gerçekçi olduğunu söylemek güçtür.

Kısacası, bağlayıcılık kapsamında Ayn Rand'ın haklı şekilde eleştirdiği etik anlayışlarında olduğu gibi kendi etik sisteminde de tatmin edici bir cevap sunamadığı soru şudur: "Niçin bu ahlaki kurallara her zaman uymak zorunda olayım?”.

Ayn Rand'ın, objektivizmin bağlayıcılık problemine bir cevap sunduğunu ispatlamak adına dünyada bir tür ödül-ceza sistemi olduğunu göstermeye çalışması ${ }^{67}$, esasen egoist bir filozof açısından gayet tutarlıdır. Her ne kadar bu tür bir ödül-ceza sisteminin dünyada her zaman geçerli olduğunu söylemek, yukarıda da üzerinde durduğumuz gibi güç olsa da bu tür mutlak bir ödül-ceza sisteminin gerçekten var olması bu sefer de başarı ile ahlakın birbirine karışmasına yol açacaktır ki bunun izlerini Ayn Rand'ın eserlerinde görmek mümkündür. Sözgelimi The Fountainheaddeki Howard Roark ve Atlas Shruggeddaki John Galt karakterleri Ayn Rand'ın ve objektivizmin ideal insanlarıdır. Fakat Nietzsche'nin übermensch'inin ${ }^{68}$ etkisinin izlerini

67 A.g.e., 37.

68 Nietzsche'nin Ayn Rand üzerindeki etkisi esasen apayrı bir çalışmayı hak edecek kadar kapsamlıdır. Ayn Rand, felsefesinin Nietzsche'ninkinden temelde tamamen farklı, hatta zıt olduğunu söylemekle birlikte (Bunun için Ayn Rand'ın Atlas Society tarafından yayınlanan 13 Aralık 1964 tarihli "Objectivism vs. Nietzscheanism" başlıklı radyo programına bakılabilir. Rand bu kayıtta tamamen objektivizmin, Nietzsche ile olan ayrlıklarından bahsetmektedir. Erişim 09.06.2021, https://www.youtube.com/watch?v=tYCCOiBSJW8) Rand'in roman karakterlerinde Nietzsche'nin hayatı olumlayan ve kendisi için yaşayan ideal insanının, yani übermensch'in etkisi bu iki filozofu okuyanlarca kolayca fark edilebilir. Ayn Rand, Nietzsche'nin felsefesinden gerçekten de pek çok yönden ayrılır ve Nietzsche'nin egoizmi ile karıştırılmamak adına gösterdiği hassasiyet bu sebeple oldukça anlaşılır bir durumdur. Öyle ki, Nietzsche'nin sübjektivizmi, akılcılı̆ga karşı olması ve aklı irade ile ikame etmesi, özdeşlik ilkesi $A=A$ yerine 'oluş'u temel alması, Rand'ın objektivizmi ile çok büyük temel farklılıklardır. Hatta Ayn Rand açısından Nietzsche 
gördügüumüz bu karakterler aynı zamanda gerçekte görmenin neredeyse imkânsız olduğu kusursuz karakterlerdir. Bu kusursuzlukları sadece ahlaklarını değil, başta meslekleri olmak üzere hayatlarının hemen her alanında son derece başarılı olmalarını da kapsamaktadır.

Başarı ile ahlakın bu derece iç içe geçmesinin yol açtığı bir diğer güçlük ise; talihsizlik, doğal felaket, yanlış hesaplama, hastalık gibi ahlaktan bağımsız sebepler yüzünden bedbaht olan insanların, objektivizmin kötü karakterleriyle aynı kadere mahkûm olacak olmalarıdır. Başarısızlık hangi noktada sadece başarısızlık, hangi noktada ahlaksızlıktır? Eğer başarısızlık, ahlaksızlık değilse, o halde çeşitli sebeplerden ötürü başarısız olan insanların kötü sonlarını objektivist etik ne ile açıklamalıdır? Dünyada kişisel çıkara dayalı bir adalet sisteminin -ki bu ancak ödül-ceza ile mümkündür- var olabilmesi için başarı, yetenek, talih gibi faktörler de ahlak ile aynı ödüle sahip olacaklardır ve böyle bir durumda yeteneksiz bir ahlaklının cezalandırılması yahut talihli bir ahlaksızın ödüllendirilmesi mümkündür. Kısacası birçok açıdan ahlaklılığı bu dünyada mutlak bir ödül-ceza sistemine tabi tutmak imkânsızdır.

\section{Sonuç}

Ayn Rand tüm etik anlayışlarını nesnellik ve akıl yerine keyfiyete dayalı oldukları gerekçesiyle reddetmektedir. Bununla beraber kurucusu olduğu objektivist etik de bu keyfiyete tabi gözükmektedir. Başkalarına zarar vermeye dayalı olan ve sağduyuya aykırı birçok muhtemel kötü eylemi, ancak objektivist ahlakın temeli olarak gösterdiği kişisel çıkarla bağdaşmayan sosyal ve politik prensipler geliştirerek kötülük olarak tanımlayabilmiştir. Bu sosyal ve politik prensipler, bireyin nihai amacı olan kendi hayatına da, ahlakının temeli olan rasyonel kişisel çıkarına da ters olabilme potansiyeline sahiplerdir ve bu nedenle hem objektivizmin kendi temeliyle çelişik hem de keyfidirler. Nihai amaç olarak hayatın kendisini ve hayatta kalmayı seçen bir ahlak anlayışı, bu nihai amaca en fazla hizmet eden her eylemi iyi ya da en azından mubah görmek durumundadır. Aksi takdirde hayata ve kişisel çıkara hizmet etseler de rastgele bazı eylemlere sosyal prensip adı altında kötü demenin tutarlı bir yanı yoktur. Öte yandan, ahlakın çıkış noktası olarak bireyin ya da daha doğru ifadeyle 'ben'in seçilmesi insan hayatına dokunan başarılı bir hamle de olsa, Ayn Rand 'ben' için ya da hayatta kalmak için faydalı olanın niçin muhakkak ahlaklı olduğuna dair yeterli gerekçe sunmamaktadır. Son olarak ahlakın bağlayıcılığı hususunda da objektivizmin açıkları vardır. Yeterince güçlü olanın niçin bu ahlaki kurallara uyması gerektiği problemine cevaben dünyada kurmaya çalıştı̆̆ 1 ahlaki ödül-ceza sistemi gerçekçi gözükmemektedir.

Ayn Rand sayısız insanın beğenisini, sayısız insanın da nefretini kazanmış, dolayısıyla kabul edilsin yahut edilmesin etkileyici bir filozoftur. Bu çalışmada onun sadece ahlak felsefesinin temeli ve bağlayıcı yönü ele alınmış, bu minvalde gerekçeler sunularak eleştiriye tabi tutulmuştur. $\mathrm{Bu}$, onun felsefesinin tamamen geçersiz ya da değersiz olduğu anlamına gelmemektedir. Aksine, iyi ya da kötü yönde pek çok kişiyi etkileyen Ayn Rand'ın, daha çok üstünde düşünülmeye ve kritik edilmeye layık olduğunu düşünmekteyim.

bir mistiktir ve objektivizmden sadece farklı değil, aynı zamanda ona karşıttır da. Fakat tüm bu farklılıklara rağmen gerek The Fountainhead deki Howard Roark, gerek Atlas Shrugged daki John Galt sadece kendi değerleri için yaşayan ve bu değerleri kendisi yaratan, ceza korkusundan dolayı değil fakat kendini olumlamak için yaşayan, güçlü ve ideal karakterler oluşlarıyla Nietzsche'nin übermensch'ini çağrıştırmaktadır. 
Hakem Değerlendirmesi: Dış bağımsız.

Çıkar Çatışması: Yazar çkar çatış,ması bildirmemiş,tir.

Finansal Destek: Yazar bu çalışma için finansal destek almadığını beyan etmiştir.

Peer-review: Externally peer-reviewed.

Conflict of Interest: The author has no conflict of interest to declare.

Grant Support: The author declared that this study has received no financial support.

\section{Kaynaklar / References}

Aristoteles. Politika. Çeviren Furkan Akderin. İstanbul: Say Yayınları, 2015.

Aristoteles. Nikomakhos'a Etik. Çeviren Furkan Akderin. İstanbul: Say Yayınları, 2014.

Avolio, Bruce J. ve Locke, Edwin E. "Contrasting different philosophies of leader motivation: Altruism versus egoism.” The Leadership Quarterly 13 (2002): 169-91.

Badhwar, Neera K. ve Long, Roderick T. "Ayn Rand”. The Stanford Encyclopedia of Philosophy, editör Edward N. Zalta, Fall 2020. Erişim 28.02.2021, https://plato.stanford.edu/archives/fall2020/entries/ayn-rand/.

Kant, Immanuel. Ablak Metafiziğinin Temellendirilmesi. Çeviren İoanna Kuçuradi. Ankara: Türkiye Felsefe Kurumu, 2002.

Machan, Tibor R. “Teaching Ayn Rand's Version of Ethical Egoism.” The Journal of Ayn Rand Studies 3, no 1 (2001): 71-81.

Machan, Tibor R. “Egoism and Benevolence.", The Journal of Ayn Rand Studies 1, no 2 (2000): 283-91.

Rand, Ayn. Atlas Vazgeçti. Çeviren Belkıs Dişbudak. İstanbul: Plato Film Yayınları, 2003.

Rand, Ayn. Bencilliğin Erdemi. Çeviren Nejat Kandemir. İstanbul: Plato Film Yayınları, 2013.

Rand, Ayn. Capitalism: The Unknown Ideal. New York: Penguin Group, 1986.

Rand, Ayn. For the New Intellectual. New York: Penguin Group, 1961.

Rand, Ayn. Philosophy: Who Needs It. New York: Penguin Group, 1984.

Rand, Ayn. Anthem. Signet, 1961.

Shaver, Robert. "Egoism”. The Stanford Encyclopedia of Philosophy, editör Edward N. Zalta, Spring 2019. Erişim 14.03.2021, https://plato.stanford.edu/archives/spr2019/entries/egoism/.

Smith, Tara. Ayn Rand's Normative Ethics: The Virtuous Egoist. New York: Cambridge University Press, 2006. 